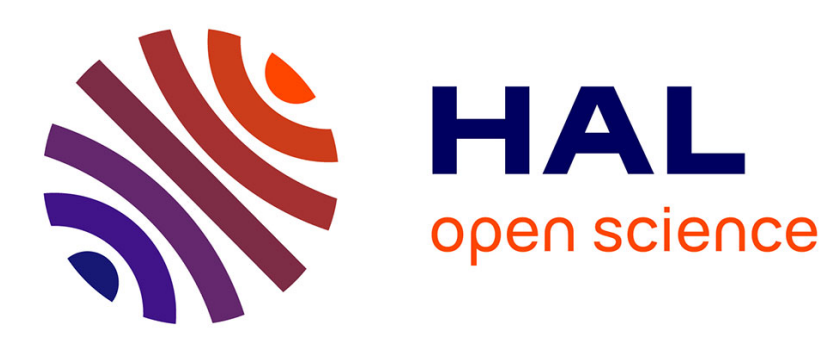

\title{
The Ganges basin geometry records a pre-15 Ma isostatic rebound of Himalaya
}

Jean-Louis Mugnier, Pascale Huyghe

\section{To cite this version:}

Jean-Louis Mugnier, Pascale Huyghe. The Ganges basin geometry records a pre-15 Ma isostatic rebound of Himalaya. Geology, 2006, 34, No. 6, pp. 445-448. 10.1130/G22089.1 . hal-00080062

\section{HAL Id: hal-00080062 \\ https://hal.science/hal-00080062}

Submitted on 14 Jun 2006

HAL is a multi-disciplinary open access archive for the deposit and dissemination of scientific research documents, whether they are published or not. The documents may come from teaching and research institutions in France or abroad, or from public or private research centers.
L'archive ouverte pluridisciplinaire HAL, est destinée au dépôt et à la diffusion de documents scientifiques de niveau recherche, publiés ou non, émanant des établissements d'enseignement et de recherche français ou étrangers, des laboratoires publics ou privés. 
Publisher: GSA

Journal: GEOL: Geology

Article ID: G22089

$1 \quad *$ E-mail: mugnier@ujf-grenoble.fr.

2 The Ganges basin geometry records a pre-15 Ma isostatic

3 rebound of Himalaya

4 Jean-Louis Mugnier*

5 Pascale Huyghe

6 CNRS, Université J. Fourier, Maison des Géosciences, BP 53, 38041, Grenoble Cedex, France

7 ABSTRACT

8 The Tertiary continental strata of the Himalayan foreland basin are subdivided in two

9 groups, but the meaning of this subdivision was previously unclear. From the analysis of drill-

10 holes, seismic lines, dated sections, field outcrops and balanced cross-sections, we find that the

11 southward migration rate of the deposition pinch-out of the younger group is $19 \pm 5 \mathrm{~mm} / \mathrm{yr}$ and

12 equals the Himalayan shortening rate. This equality shows that the flexural foreland basin

13 development is mainly controlled by the motion of the thrust load. The long-term pinch-out

14 migration rate was slower for the older syn-orogenic group. Erosion locally occurred at the end

15 of its deposition, due to tectonic reactivation of lineaments of the Indian shield. We suggest that

16 this change in the basin development is linked to the detachment of the subducted Indian

17 lithosphere that decreased the slab pull and increased the mean compressive stress within the

18 Indian plate, whereas the plate motion remained constant. The most important implication of our

19 work is that the associated isostatic rebound could increase the Himalayan elevation prior 15 Ma.

20 Keywords: Himalaya, flexure, foreland basin, relief, slab break-off, tectonic reactivation.

21 INTRODUCTION 
Publisher: GSA

Journal: GEOL: Geology

Article ID: G22089

The timing of the rise of Himalaya is of great importance because Himalaya is the best

23 example when trying to understand the relation between mountain belt tectonics and

24 paleoclimate (Molnar et al., 1993; Zhisheng et al., 2001; Spicer et al., 2003). But this rise is

25 highly debated, because there is no direct measurement of paleo-elevation. Therefore,

26 geodynamical models that take into account the role of isostasy and horizontal stresses remain a

27 powerful approach to deduce the relief evolution of a mountain belt (Molnar et al., 1993). In this

28 paper, we hypothesize that the overall foreland basin geometry of the Ganga basin is controlled

29 by flexural subsidence related to the neighbor Himalayan belt evolution. The basin geometry is

30 used to specify the evolution of the stress that affected the Indian shield and to propose an

31 evolution of the lithospheric root and relief of the Himalayan belt.

\section{GEOLOGICAL SETTING}

The Indian shield was affected by several tectonic events before the convergence of India

toward Asia. Its northern part was strongly affected by the formation of a Proterozoic fold belt

35 and the Proterozoic to Cambrian Vindhyan basin (Shukla and Chakravorty, 1994). Therefore, the

36 crust beneath the Ganga basin (Fig. 1) is affected by inherited tectonic lineaments. These

37 lineaments delineate from NW to SE a succession of spurs and depressions in the Tertiary Ganga

38 basin (Raiverman et al., 1994) and are very oblique to the structural trend of the Himalayan

39 thrust belt (Powers et al., 1998). This thrust belt induces a flexural subsidence that is the prime

40 control of the foreland basin development (Burbank et al., 1996). The depotcenter was located

41 close to the front of the collision belt (Fig. 2) and the sediment pinch-out migrated outwards

42 (Lyon-Caen and Molnar, 1985) due to the motion of the thrust wedge (Huyghe et al., 2001).

Two groups define the syn-orogenic continental sediments of the foreland basin: the pre-

44 Siwalik and the Siwalik group (Burbank et al., 1996; Najman et al., 2004). The lithostatigraphic 
Publisher: GSA

Journal: GEOL: Geology

Article ID: G22089

45 distinction between the continental strata of the Pre-Siwalik and Siwalik group has been defined

46 very early (Meddlicott, 1884), and the main distinction is the extent of the sedimentation

47 domains. The base of the Siwalik group is at ca. 13 Ma in India (Najman et al., 2004) and older

48 than 15.5 Ma in Nepal (Gautam and Fujiwara, 2000).

DEPOSITION PINCH-OUT MIGRATION RATE AND HIMALAYAN SHORTENING

RATE DURING THE SIWALIK STAGE

A previous estimate of the pinch-out migration rate was obtained from 8 drill-holes

52 (Lyon-Caen and Molnar, 1985). This result is revisited from a compilation of 26 drill-holes

53 (Valdiya, 1980; Acharyya and Ray, 1982; Raiverman et al., 1994; Shukla and Chakravorty,

54 1994; Srinivasan and Khar, 1996; Bashial, 1998; Powers et al., 1998) and 5 outcrops of the

55 Tertiary basal unconformity (Valdiya, 1980; Shresta and Sharma 1996; Sakai et al., 1999) (Table

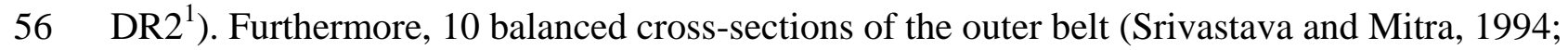

57 Srinivasan and Khar, 1996; Powers et al., 1998; Lavé and Avouac, 2000; Mishra, 2001; Mugnier

58 et al., 2004) are used to estimate the displacement of the thrust sheets. The method of analysis is

59 detailed in the Table DR2 ${ }^{1}$. The Siwalik group is informally subdivided into lower, middle and

60 upper lithostratigraphic units (Lyon-Caen and Molnar, 1985) and the age of the Siwalik units in

61 the drill-holes is estimated from the nearest, amongst eleven, magnetostratigraphic studies (Fig. 1

62 and Table DR1 ${ }^{1}$ ) (Burbank et al., 1996; Gautam and Rosler, 1999; Brozovic and Burbank, 2000;

63 Gautam and Fujiwara, 2000). Nonetheless, these lithostratigraphic boundaries are diachronic at

\footnotetext{
${ }^{1}$ GSA Data Repository item 2004070. Table DR1, Age of the Tertiary lithostratigraphic units inferred from magnetostratigraphic studies and others methods, Table DR 2, The migration of the pinch-out of the Tertiary basin, and Table DR3, Shortening rate estimate through the central Himalaya.
} 
Publisher: GSA

Journal: GEOL: Geology

Article ID: G22089

64 local scale (Brozovic and Burbank, 2000; Huyghe et al., 2005) and along cross-sections

65 transverse to the foreland basin (Lyon-Caen and Molnar, 1985). We take into account this

66 diachronism to estimate the age uncertainty (see $\mathrm{DR} 2^{1}$ ), leading to a smaller uncertainty to the

67 pinch-outs located close to the dated sections.

68 We find that the pinch-out migration rate varies laterally for the Siwalik period. It is $19 \pm$

$695 \mathrm{~mm} / \mathrm{yr}$ in front of the central part of Himalaya and only $12 \pm 3 \mathrm{~mm} / \mathrm{yr}$ in the western part (Fig.

70 3). This lateral variation mimics the variation of the shortening rate: in central Himalaya, the

71 shortening rate is $20 \pm 5 \mathrm{~mm} / \mathrm{yr}$ (De Celles et al., 2002; Mugnier et al., 2004) (Fig. 3, DR $3^{1}$ ), and

72 in western part is $14 \pm 4 \mathrm{~mm} / \mathrm{yr}$ (Powers et al., 1998).

73 Our data sets are based on independent estimation procedures of the shortening and

74 pinch-out migration rates and confirm their equality previously postulated by Lyon-Caen and

75 Molnar (1985). Therefore our work reinforces the hypothesis that a flexural behavior of the

76 lithospheric plate links the evolution of the Ganga basin to the translation of the Himalayan belt.

77 Furthermore, the mean slope and the topography of the belt have probably not greatly changed

78 since at least $15 \mathrm{Ma}$, because the Himalayan wedge migrates only if its taper is maintained

79 (Dahlen and Barr, 1989).

80

\section{THE EVOLUTION OF THE BASIN PRIOR TO THE SIWALIK DEPOSITION}

The pre-Siwalik group is formed of continental strata with an age between $13 \mathrm{Ma}$ and less

82 than 30 Ma (Sakai et al., 1999; Najman et al., 2004). The pre-Siwalik basin is restricted to the

83 very northern part of the Ganga plain (Raiverman et al., 1994), to the footwall of the basal

84 décollement of the Sub-Himalaya zone (Powers et al., 1998) and to the top of few tectonic

85 Himalayan slices (Najman et al., 2004). An “intermediate sequence” (Fig. 2A) beneath the

86 Ganga basin was initially interpreted as part of the Tertiary group (Lyon-Caen and Molnar, 
Publisher: GSA

Journal: GEOL: Geology

Article ID: G22089

87 1985), but further works suggest that it consists of Vindhyan deposits (Srinivasan and Khar,

88 1996).

The southward migration rate of the pinch-out for the pre-Siwaliks (Fig.3) is smaller than

90 the migration rate for the Siwaliks. We discuss in the following six different hypotheses to

91 explain this change: 1) variation of the rigidity of the flexed plate (Waschbuch and Royden,

92 1992); 2) onset of a thrusting event (Fleming and Jordan, 1990); 3) internal thickening and

93 narrowing of the thrust belt (Sinclair et al., 1991); 4) change in the shortening rate; 5) erosional

94 unloading of the topographic wedge (Burbank, 1992); 6) lost of the heavy roots of the orogen

95 (Sinclair, 1997).

A variation of the rigidity of the flexed plate is unlikely, because the rigidity was already

97 great during the pre-Siwalik stage, due to the old (more than $500 \mathrm{Ma}$ ) thermotectonic age of the

98 Indian lithosphere (Burov and Diament, 1995). Furthermore, flexural modelling of the Eocene-

99 early Miocene foreland basin indicates a flexural rigidity greater than $7 \cdot 10^{23} \mathrm{Nm}$ (De Celles et

100 al., 1998), a value close to the present-day rigidity in central Himalaya (Lyon-Caen and Molnar, 101 1985).

EROSION AND TRANSPRESSION AT THE BASE OF THE SIWALIK GROUP

104 hypotheses proposed for the change of the migration rate.

105 Seismic data beneath the Ganga plain and the sub-Himalayan thrust belt (DMG, 1990;

106 Shukla and Chakravorty,1994; Srinivisan and Khar, 1996; Raiverman et al., 1994) indicate that

107 the partitioning of the Ganges basin in a succession of spurs and depressions is controlled by

108 basement fault reactivation (Raiverman et al., 1994; Bashial, 1998). These spurs influenced the

109 thickness and the southern depositional limits of the Pre-Siwalik group (Raiverman et al., 1994). 
Publisher: GSA

Journal: GEOL: Geology

Article ID: G22089

110 Locally, the south boundary of the upper sub-group is located to the north of the pinch-out of the

111 underneath sub-group (Raiverman et al., 1994). This apparent backward migration is due to

112 erosion that had removed the southern part of the upper sub-group (Fig. 2A and B) beneath

113 unconformities (Fig. 2C) at the top of the Pre-Siwalik sub-group. This retrogradation causes the

114 reduction of the long term pinch-out migration rate, though the "instantaneous" Eocene-early

115 Miocene and late Miocene-Pliocene migration rate could be similar (De Celles et al., 1998).

116 These unconformities, though largely extended (Pascoe, 1964), are discontinuous

117 laterally (Raiverman et al., 1994). The erosion seems mainly expressed above the basement

118 faults and the complex pattern of the sedimentary bodies suggests a left-lateral transpressional

119 tectonic regime along the lineaments oblique to the Himalayan trend. Normal faults, parallel to

120 the Himalayan trend, throw down toward the north the base of the Tertiary strata (Raiverman et

121 al., 1994) (Fig. 2B). They are related to the reactivation of Indian shield lineaments due to the

122 negative curvature of the flexed lithosphere during the pre-Siwalik stage (Powers et al., 1998)

123 and positive structural inversion (Gillcrist et al., 1987) leads to basement folding at their

124 hanging-wall at the end of the pre-Siwalik stage. Therefore, a phase of fault reactivation is

125 synchroneous with local erosion or deposition of the uppermost pre-Siwalik sequence and

126 predates $15.5 \mathrm{Ma}$ in Nepal and $13 \mathrm{Ma}$ in India. This phase was linked to an increase of the mean

127 horizontal forces applied by the plate motion close to the orogen area and/or a decrease of the

128 bending moment that controls the curvature of a flexed plate.

FLEXURE OF THE INDIAN PLATE: THE ROLE OF THE CRUSTAL

130 LOADING OF THE THRUST WEDGE VERSUS LITHOSPHERIC SLAB BREAK-OFF

131 Onset of a thrusting event and internal thickening of the thrust belt would change the

132 geometry of the crustal thrust wedge (Fleming and Jordan, 1990; Sinclair et al., 1991), leading to 
Publisher: GSA

Journal: GEOL: Geology

Article ID: G22089

133 a retrogradation of the pinch-out and also an increase of the curvature of the flexed lithosphere.

134 Such a curvature increase stage does not match to a stress increase, and we therefore exclude 135 these hypotheses for the transition between pre-Siwalik and Siwalik stage.

136 Shortening rate during the pre-Siwalik stage is $20 \pm 8 \mathrm{~mm} / \mathrm{yr}$ (Fig. 3). Choosing the lower

137 value of $12-14 \mathrm{~mm} / \mathrm{yr}$ would keep equal shortening rate and migration rate. Therefore, an

138 increase of the shortening at the end of the pre-Siwalik stage would explain the stress increase.

139 We nonetheless do not favour this interpretation because it is associated with a constant

140 convergence between India and Eurasia (DeMets et al., 1990) and an increasing erosion of

141 Himalaya (Clift et al., 2004; Bernet et al., 2005).

142

This regional increase of the erosion could drive an erosional unloading (Burbank, 1992)

143 at the Siwalik/pre-Siwalik transition. Nonetheless, erosional unloading would imply that erosion

144 exceeded the volume of rocks moved by tectonics above the Indian plate. A lower bound for the

145 rate of tectonic loading is the product of the lower estimate of the shortening $(12 \mathrm{~mm} / \mathrm{yr})$ by the

146 lower estimate of the thrust thickness $(20 \mathrm{~km})$. Therefore the erosion would have to exceed 240

$147 \mathrm{~m}^{3} / \mathrm{yr}$ for a swath of $1 \mathrm{~m}$, or $0.5 \mathrm{~km}^{3} / \mathrm{yr}$ for the whole Himalaya, i.e., to be as great as the Plio-

148 Quaternary erosion estimated by Métivier et al. (1999). No data suggests such a regional peak of 149 erosion by that time.

150 We rather suggest that a lithospheric slab break-off increased the relief and consequently

151 the erosion. This slab break-off increased the stresses within the Indian plate through two

152 processes: a) The loss of the mantle lithospheric roots decreases the additional forces exerted at

153 the trailing edge of the flexed lithosphere (Lyon-Caen and Molnar, 1985) and decreases the

154 curvature of the plate; b) The loss of the continental mantle lithospheric roots increases the mean

155 horizontal deviatoric forces applied by the orogen area and surrounding lowlands to one another 
Publisher: GSA

Journal: GEOL: Geology

Article ID: G22089

156 (Molnar et al., 1993). Tomographic analysis (Van der Voo et al., 1999) suggests that several

157 detached portions of the lithospheric mantle are located beneath Tibet and Himalaya, due to a

158 delamination of the Indian continental mantle and its break-off. Such a break-off (Fig. 4) fits

159 with the Neogene magmatic evolution of Southern Tibet (Mahéo et al., 2002). We suggest, from

160 the timing of the fault reactivation beneath the foreland basin, that the break-off was achieved

161 before 15.5 Ma in Central Himalaya and progressively propagated westward over several

162 millions years.

163 Numerical models (Buiter et al., 2002) indicate that the break-off related-uplift zone is

164 much larger than an uplift zone at the hanging-wall of any mega thrust fault (Beaumont et al.,

165 2001), but it is much smaller than the width of Tibet. The Tibetan uplift is probably linked to

166 several processes, and the slab break-off could be one of them. It induced a kilometer-scale

167 increase of the altitude of the very southern part of the Tibetan plateau and led to topographic

168 emergence of a discrete Himalaya belt with respect to Tibetan plateau prior to 15 Ma.

169 ACKNOWLEDGMENTS

170 We thank M. Bernet and S. Guillot for numerous comments of the manuscript. The reviews of H.

171 Sinclair and D. Burbank were very helpful to clarify the discussion. This work is granted by

172 “Eclipse” and “Relief” French programs.

173 REFERENCES CITED

174 Acharyya, S., and Ray, K., 1982, Hydrocarbon Possibilities of Concealed Mesozoic-Paleogene

175 sediments below Himalayan Nappes- reappraisal: The American Association of Petroleum

176 Geologist Bulletin, v. 66, p. 57-70.

177 Bashial, R.P., 1998, Petroleum exploration in Nepal: Journal of Nepal Geological Society, v. 18,

178 p. 19-24. 
Publisher: GSA

Journal: GEOL: Geology

Article ID: G22089

179 Beaumont, C., Fullsack, P., and Hamilton, J., 2001, Himalayan tectonics explained by extrusion

180 of a low-viscosity crustal channel coupled to focused surface denudation: Nature, v. 414,

181 p. $738-742$, doi: $10.1038 / 414738$.

182 Bernet, M., Van Der Beek, P., Huyghe, P., and Mugnier, J.-L., 2005, Continuous and episodic 183 exhumation of the Central Himalayas from detrital zircon fission-track analysis of Siwalik 184 sediments, Nepal. 20TH HKT Workshop, Aussois, France, abstracts volume, p.10.

185 Brozovic, N., and Burbank, D., 2000, Dynamic fluvial systems and gravel progradation in the 186 Himalayan foreland: Geological Society of America Bulletin, v. 112, p. 394-412, doi: 10.1130/0016-7606(2000)112<0394:DFSAGP>2.3.CO;2.

Buiter, S., Govers, R., and Wortel, M.J.R., 2002, Two-dimensional simulations of surface deformation caused by slab detachment: Tectonophysics, v. 354, p. 195-210, doi: 10.1016/S0040-1951(02)00336-0.

191 Burbank, D.W., 1992, Causes of recent uplift deduced from deposited pattern in the Ganges 192 basin: Nature, v. 357, p. 680-683, doi: 10.1038/357680a0.

193 Burbank, D.W., Beck, R.A., and Mulder, T., 1996, The Himalayan Foreland: in Asian Tectonics (edited by A. Yin and T.M. Harrison). Cambridge University Press, Cambridge, p. 149-

Burov, E., and Diament, M., 1995, The effective elastic thickness of continental lithosphere: what does it mean?: Journal of Geophysical Research, v. 100, p. 3905-3927, doi: 10.1029/94JB02770.

199 Clift, P.D., Layne, G.D., and Blusztajn, J., 2004, Marine Sedimentary evidence for monsoon strengthening, Tibetan uplift and drainage evolution, in Clift, P.D., Wang, P., Hayes, D., 
Publisher: GSA

Journal: GEOL: Geology

Article ID: G22089

and Kuhnt, Continent-Ocean Interactions in the East Asian Marginal Seas: American Geophysical Union, Monograph, series 149, p. 255-282.

Dahlen, F., and Barr, T., 1989, Brittle frictional mountain building- deformation and mechanical energy budget: Journal of Geophysical Research, v. 94, p. 3906-3922.

De Celles, P.G., Gehrels, G.E., Quade, J., and Ojha, T.P., 1998, Eocene-early Miocene foreland basin development and the history of the Himalayan thrusting, western and central Nepal: Tectonics, v. 17, p. 741-765, doi: 10.1029/98TC02598.

De Celles, P.G., Robinson, D., and Zandt, G., 2002, Implication of shortening in the Himalayan fold-thrust belt for uplift of the Tibetan plateau: Tectonics, v. 21, p. 1062, 1087.

DeMets, C., Gordon, G., Argus, D., and Stein, S., 1990, Current plate motion: Geophysical Journal International, v. 101, p. 425-478.

DMG, 1990, Nepal exploration opportunities: Department of Mines and Geology - Ministry of Industry His Majesty’s Government of Nepal, Kathmandu, 30 p.

Fleming, P., and Jordan, T.,1990, Stratigraphic modelling of foreland basins: interpreting thrust deformation and lithosphere rheology, Geology, v. 18, p. 430-434.

216 Gautam, P., and Fujiwara, Y., 2000, Magnetic polarity stratigraphy of Siwalik group sediments

219 Gautam, P., and Rosler, W., 1999, Depositional Chronology and fabric of Siwalik group of Karnali River section in western Nepal: Geophysical Journal International, v. 142, p. 812-824, doi: 10.1046/j.1365-246x.2000.00185.x sediments in Central Nepal from magnetostratigraphy and magnetic anisotropy: Journal of Asian Earth Sciences, v. 17, p. 659-682, doi: 10.1016/S1367-9120(99)00021-8.

Gillcrist, R., Coward, M., and Mugnier, J.L., 1987, Structural inversion and its controls: examples from the Alpine foreland and the French Alps: Geodinamica Acta, v. 1, p. 5-34. 
Publisher: GSA

Journal: GEOL: Geology

Article ID: G22089

224 Huyghe, P., Galy, A., Mugnier, J.-L., and France-Lanord, C., 2001, Propagation of the thrust

225 system and erosion in the Lesser Himalaya: Geochemical and sedimentological evidence:

226 Geology, v. 29, p. 1007-1010, doi: 10.1130/0091-

7613(2001)029<1007:POTTSA>2.0.CO;2.

228 Huyghe P., Mugnier J.L., Gajurel A., and Delcaillau B., 2005, Tectonic and climatic controls of

229 the changes in the sedimentary record of the Karnali river section (Western Nepal), Island

$230 \quad$ Arc, v. 14, p. 311-327.

231 Lavé, J., and Avouac, J.P., 2000, Active folding of fluviatile terraces across the Siwaliks hills,

232 Himalayas of central Nepal, implications for himalayan seismotectonics: Journal of

233 Geophysical Research, v. 105, p. 5735-5770, doi: 10.1029/1999JB900292.

234 Lyon-Caen, H., and Molnar, P., 1985, Gravity anomalies, flexure of the Indian plate, and the

235

236

structure, support and evolution of the Himalaya and Ganga basin: Tectonics, v. 4, p. 513538.

237 Mahéo, G., Blichert-Toft, G., Rolland, Y., and Pêcher, A., 2002, A slab breakoff model for the

238 Neogene thermal evolution of South Karakorum and South Tibet: Earth and Planetary

239 Science Letters, v. 195, p. 45-58, doi: 10.1016/S0012-821X(01)00578-7.

240 Meddlicott, H., 1884, On the geological structures and relations of the southern position of the

241 Himalayan ranges between the rivers Ganges and Ravee: Indian Geological Survey

242 Memory, v. 3, p. 1-206.

243 Métivier, F., Gaudemer Y., Tapponier, P., Klein, M., 1999, Mass accumulation rates in Asia

244 during the Cenozoic: Geophysical Journal International, v. 137, p. 280-318, doi:

$245 \quad$ 10.1046/j.1365 246X.1999.00802.x. 
Publisher: GSA

Journal: GEOL: Geology

Article ID: G22089

246 Mishra, P., 2001, Balanced cross sections, structural evolution and shortening, NW Himalayan

247 fold-thrust belt: Unpublished Ph.D. thesis, Indian Institute of Technology Roorkee, India, $248280 \mathrm{p}$.

249 Molnar, P., England, P., and Martinod, J., 1993, Mantle dynamics, uplift of the Tibetan Plateau 250 and the Indian Monsoon: Reviews of Geophysics, v. 31, p. 357-396, doi: 10.1029/93RG02030.

252 Mugnier, J.L., Huyghe, P., Leturmy, P., and Jouanne, F., 2004, Episodicity and rates of thrust sheet motion in Himalaya (Western Nepal), in "Thrust Tectonics and Hydrocarbon Systems:

255 Najman, Y., Johnson, K., White, N., and Grahame, O., 2004, Evolution of the Himalayan 256 foreland basin, NW India: Basin Research, v. 16, p. 1-24, doi: 10.1111/j.13652117.2004.00223.x.

258 Pascoe, E., 1964, A manual of Geology of India and Burma: Gov. of India Publication, Dehli, p. $2592130 \mathrm{p}$.

260 Powers, P.M., Lillie, R.J., and Yeats, R.S., 1998, Structure and shortening of the Kangra and 261 Dehra Dun reentrants, Sub-Himalayas, India: Geological Society of America Bulletin, v. 110, p. 1010-1027, doi: 10.1130/0016-7606(1998)110<1010:SASOTK>2.3.CO;2.

Raiverman, V., Chugh, M., Srivastava, A., Prasad, D., and Das, S., 1994, Cenozoic Tectonic of frontal fold belt of the Himalaya and Indo-Gangetic Foredeep with pointers Towards Hydrocarbon Prospects: Proc. Second seminar on Petroliferous Basins of India, 3, S.K. Biswas et al. (eds), Indian Petroleum Publishers, Dehra Dun, 248001, India, p. 25- 54. Pre-siwalik foreland basin sediments beneath the crystalline nappe, western Nepal, 
Publisher: GSA

Journal: GEOL: Geology

Article ID: G22089

Himalaya: Journal of Asian Earth Sciences, v. 17, p. 727-741, doi: 10.1016/S1367-

271 Shresta, R.B., and Sharma, S.R., 1996, The lower Siwalik-basement unconformity in the Sub-

272 Himalaya of eastern Nepal and its significance: Journal of Nepal Geological Society, v. 13,

273 p. 29-36.

274 Shukla, S.N., and Chakravorty, D., 1994, Status of exploration and future programme of

275 Hydrocarbon exploration in Vindhyan and Gondwana Basins: Proc. Second seminar on

276 Petroliferous Basins of India, 3, S.K. Biswas et al. (eds), Indian Petroleum Publishers, Dehra

277 Dun, 248001, India, p. 63-100.

278 Sinclair, H., Coakley, B., Allen, P., and Watts, A., 1991, Simulation of foreland basin

279

280

281 stratigraphy using a diffusion model of mountain belt uplift and erosion: an example from the central Alps, Switzerland, Tectonics, v. 10, p. 599-620.

Sinclair, H., 1997, Flysh to molasses transition in peripheral foreland basins: The role of the passive margin versus slab breakoff, Geology, v. 25, p. 1123-1126.

283 Spicer, R.A., Harris, N.B.W., Widdowson, M., Herman, A.B., Guo, S., Valdes, P.J., Wolfe, J.A., 284 and Kelley, S.P., 2003, Constant elevation of southern Tibet over the past 15 million years: Nature, v. 421, p. 622-624, doi: 10.1038/nature01356.

Srinivasan, S., and Khar, B.M., 1996, Status of hydrocarbon exploration in Northwest Himalaya and foredeep- Contribution to stratigraphy and structure: Geological Survey of India Special Publication 21, p. 295-405.

Srivastava, P., and Mitra, G., 1994, Thrust geometries and deep structures of the outer and lesser Himalaya, Kumaon and Garhwal (India): Implications for evolution of the Himalayan fold and thrust belt: Tectonics, v. 13, p. 89-109, doi: 10.1029/93TC01130. 
Publisher: GSA

Journal: GEOL: Geology

Article ID: G22089

292 Valdiya, K.S., 1980, Geology of the Kumaon lesser Himalaya: Published by Wadia Institute of

293 Geology, Dehradun, India, 291 p.

294 Van der Voo, R., Spakman, W., and Bijwaard, H., 1999, Tethyan subducted slabs under India:

295 Earth and Planetary Science Letters, v. 171, p. 7-20, doi: 10.1016/S0012-821X(99)00131-4.

296 Waschbuch P.J., Royden, L.H., 1992, Neogene kinematics of the central and western Alps:

episodicity in foredeep basins, Geology, v. 20, p. 915-918.

298 Zhisheng, A., Kutzbach, J., Prell, W., and Porter, S., 2001, Evolution of Asian monsoons and

299 phased uplift of the Himalaya-Tibetan plateau since late miocene times: Nature, v. 411,

$300 \quad$ p. $62-66$, doi: $10.1038 / 35075035$.

301

302 Figure 1. Structural sketch of the Himalaya and its foreland basin. $\mathrm{Cu}$-Magnetostratigraphic 303 studies of the Tertiary units (see Table DR $1^{1}$ ). $・$ Dr—Drill holes (or outcrops) of the base of the

304 Tertiary sediments (see Table DR2 ${ }^{1}$ ). 1—Himalaya. 2—sub-Himalaya. 3—foreland basin. 4—

305 Indian shield. 5—Linaments beneath the Ganga foreland basin from Raiverman et al. (1994) and

306 Srinivasan and Khar (1996). 6-Main Himalayan Thrusts. 7— Pinch-out of the pre-Siwalik

307 group from DMG (1990), Shresta and Sharma (1996), Srinivasan and Khar (1996) and

308 Raiverman et al. (1994). 8 - Southern edge line of the basin from Lyon-Caen and Molnar

309 (1985).

310

311 Figure 2. Cross-sections through the Tertiary sediments. The vertical scale is magnified by 5 . A:

312 Cross-section through the foreland basin. Ages refer to the pinch-out: 1—Siwalik group; 2-

313 Tertiary pre-Siwalik group; 3-Pre-Tertiary sequences. BF-Reactivation of an Indian shield

314 lineament. Northern part of the Tertiary basin from Raiverman et al. (1994) and southern part 
Publisher: GSA

Journal: GEOL: Geology

Article ID: G22089

315 from Shukla and Chakravorty (1994); intermediate sequence from Srinivasan and Khar (1996),

316 basement structures from Shukla and Chakravorty (1994). B: Structure of the Tertiary sediments

317 beneath the sub-Himalayan belt of Dehra-Dun area from Raiverman et al. (1994) and Powers et

318 al. (1998). MFT: Main Frontal Thrust; MBT: Main Boundary Thrust. Same scale for cross-

319 section A and B. The thickness of pre-Siwalik sediments greatly varies close to the Mohand drill-

320 hole. C: Zoom of a seismic profile (Location on Fig. 2B). Beneath the sub-Himalayan belt,

321 toplaps occur beneath an unconformity at the base of the Siwaliks. Paleo-relief is preserved

322 beneath the lower Siwaliks at the hanging-wall of steep faults. These faults are cut and

323 transported by the basal décollement of the sub-Himalayan zone.

324

325 Figure 3. A plot of the age of the base of the Tertiary sediments versus the distance from the

326 edge of the Ganges basin. Circles, squares, continuous and hached lines refer respectively to

327 drill-holes east of $\mathrm{E}^{\circ} 8^{\circ}$ and west of $\mathrm{E}^{\circ} 8^{\circ}$, and to the cross-section of Figure 2B (see Table

328 DR2 ${ }^{1}$ ). The thick $\times$ refer to a plot of time versus Himalayan shortening (see Table DR3 ${ }^{1}$ ) and

329 the hatched line is a linear fit for these data.

331 Figure 4. A sketch of the Ganges basin-Himalaya-Tibet evolution. The vertical scale is

332 magnified by 5 for the uppermost crust (shallower than $10 \mathrm{~km}$ ) to see the foreland basin and the

333 Himalayan relief. The lithospheric structures are not vertically magnified. 1-Tertiary foreland

334 basin; 2—Crust of the Indian shield; 3-Himalaya; 4-Tibetan Zone; 5-Indian lithospheric

335 mantle. MFT: Main Frontal Thrust; MCT: Main Central Thrust. A: Geometry at ca. 20 Ma. B:

336 Geometry at ca. 15 Ma. Lithospheric mantle break-off induced (1) an increase of the stresses and

337 (2) fault reactivation in the Indian shield, (3) local erosion of the foreland basin, (4) increase of 
Publisher: GSA

Journal: GEOL: Geology

Article ID: G22089

338 the altitude of the Himalaya (uplift profile adapted from Buiter et al.; 2002), and (5) volcanism in

339 southern Tibet. C: Present day state. 


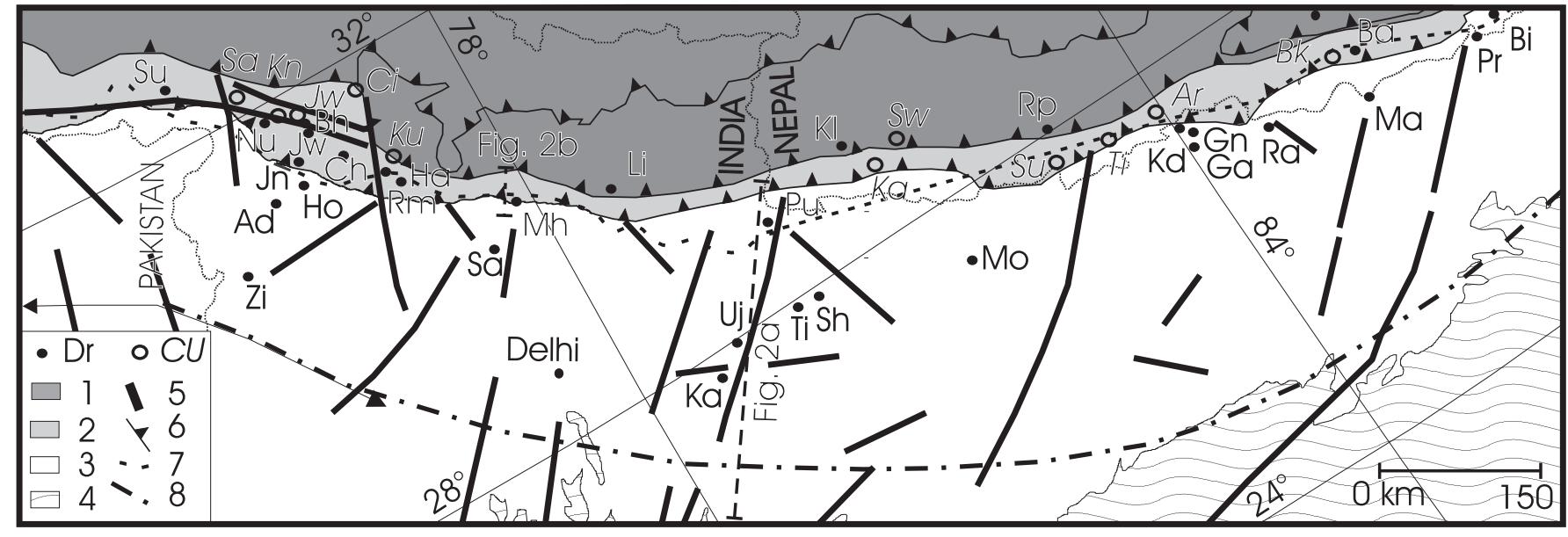

Fig. 1 


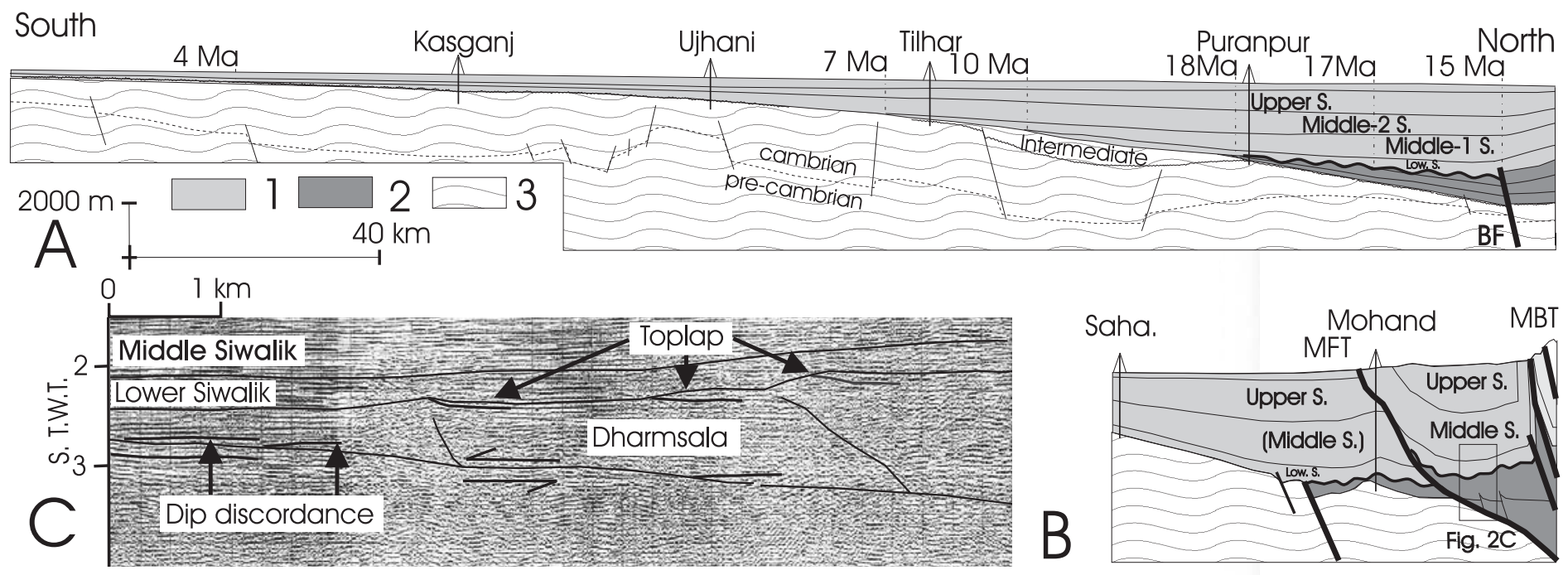


